\title{
The Role and Importance of the Transactions Costs Theory in Agricultural Contracting Area: an Appraisal of Selected Empirical Studies
}

\author{
Norsida binti Man ${ }^{1}$, Zuhal Rdhaiwi Kadhim ${ }^{2}$, Ismail b Abd Latif ${ }^{3}$, and Kelly \\ Wong Kai Seng ${ }^{4}$ \\ ${ }^{1}$ Associate Professor (Ph.D.), Department of Agribusiness and Bio resources Economic, Faculty of Agriculture, \\ Universiti Putra Malaysia, 43400 UPM Serdang, Selangor, Malaysia. \\ Phone: +6012-3993872 E-mail: norupi45@yahoo.com \\ ${ }^{2}$ Corresponding Author, Graduate Research Fellow, Department of Agribusiness and Bio resources Economic, \\ Faculty of Agriculture, Universiti Putra Malaysia, 43400 UPM Serdang, Selangor, Malaysia, lecturer in \\ Baghdad University, Agriculture College. \\ Phone:+6018-3939807 E-mail: Zuhal_khadim@yahoo.com \\ ${ }^{3}$ Assistance professor (Ph.D.), Department of Agribusiness and Bio resources Economic, Faculty of Agriculture, \\ Universiti Putra Malaysia, 43400 UPM Serdang, Selangor, Malaysia. \\ Phone: +603-8947 4902 E-mail: ial@upm.edu.my \\ ${ }^{4}$ Senior Lecturer (Ph.D.), Department of Agribusiness and Bio resources Economic, Faculty of Agriculture, \\ Universiti Putra Malaysia, 43400 UPM Serdang, Selangor, Malaysia. \\ Phone:+603-89474904 E-mail: kellywong@upm.edu.my
}

\begin{abstract}
Formal contractual arrangements cover a considerable share of globe agricultural production. Agricultural contracts can have many beneficial effects. They can help farmers manage price and production risks, thus encouraging more efficient use of farm and processing capacities. But contracts can also have less benign effects. They can introduce new and unexpected risks for farmers-in some circumstances, they can extend a buyer's market power- and they can effect fundamental changes in how farming is organized and carried out. In this our article we address transaction cost theory (TCT) in some details as a theoretical framework in study of methodology of agreements and contracts, for proving the role and importance of this theory on agriculture contracting area based on eight empirical studies on assessing transaction costs in different farms. Main finding is there are diverse opinions on the applicability of the transaction costs theory in agricultural contracting scope of different management decision-making processes. These opinions developed over a long period of time following continuous improvement on the application of the theory in solving of the outsourcing business problems. These studies also proved that transaction costs are difficult to measure and there is no standard procedure to assess transaction costs, but they can and should be estimated because they are important cost elements in the decision-making process concerning the choice of contract for different outsourcing agricultural production stages.
\end{abstract}

Keywords: Agricultural contracts; spot markets; transaction cost theory; governance structures; contracts matrix.

\section{Introduction}

Formal contractual arrangements cover a considerable share of globe agricultural production. Contracting is associated with other features of ongoing structural change in agriculture, including shifts of production to larger farms, increased farm specialization, and greater product differentiation (Key, 2004). Many farm product transactions are organized through agreements between farmers and buyers that are reached prior to harvest (or before the completion of a production stage, as in the case of livestock) and that govern the terms under which products are transferred from the farm (U.S. Department of Agriculture, 2010). Contracts provide for much closer linkages between farmers and specific buyers than spot markets and may provide the contractor/buyer with greater control of agricultural production decisions. Specific contractual designs in agriculture vary, but we find that a simple two-way classification is informative (Macdonald, 2011):

1. Production contracts specify services provided by a farmer for a contractor who owns the commodity while it is being produced. The contract covers: the services provided by the farmer, the manner in which the farmer is to be compensated for the services, and the specific contractor responsibilities for provision of inputs. For example, farmers provide labor, housing, and equipment under livestock and poultry production contracts, while contractors provide such other inputs as feed, veterinary and livestock transportation services, and young animals. The farmer's payment resembles a fee paid for the specific services provided by the farmer, instead of 
a payment for the market value of the product. Since contractor- provided inputs may account for a large share of production costs, the fee paid to the farmer may be a small fraction of the commodity's value.

2. Marketing contracts focus on the commodity as it is delivered to the contractor, rather than on the services provided by the farmer. They specify a commodity's price or a mechanism for determining the price, a delivery outlet, and a quantity to be delivered. The parties in a marketing contract agree to its terms before harvest or, for livestock, before transfer. We consider agreements reached on harvested commodities in storage to be cash market sales. Forward cash contracts are one type of marketing contract, in which a specific price is agreed upon at the time of the agreement, with the commodity to be delivered at a later agreed-upon date. But other types of marketing contracts, often of longer duration, specify a method or formula for determining prices, rather than a specific price, at the time of agreement. Contract pricing mechanisms may limit a farmer's exposure to the risks of wide fluctuations in market prices, and they often specify price premiums to be paid for commodities with desired levels of specified attributes (such as oil content in corn or leanness in hogs). The farmer owns the commodity during production and retains substantial control over major management decisions, with limited direction from the contractor, and, hence, retains more autonomy in decision making than is available under production contracts. Contracts offer several advantages to farmers (Macdonald, 2004). First, they reduce the income risks that arise from fluctuations in commodity prices and yields. Second, contracts can assure farmers of outlets for commodities in markets with few buyers and, thus, assure a better return on investments in physical capital and time. Finally, contracts can also tie prices more closely to product attributes and, thereby, provide returns to farmers who can provide that attributes.

The study of methodology of agreements and contracts includes seven different theories that are:

1. Life cycle theory.

2. Transaction cost theory.

3. Strategic management theory.

4. Negotiating power and preference incentives theory.

5. The capabilities approach theory.

6. Convention theory and contract economics.

7. Value differentiation and complementarities.

Therefore, in this our article we address transaction cost theory in some details due to its importance in economics studies related to decision making processes.

A transaction is a process by which a product or service is transferred across a technologically separable interface (Williamson, 1985). In classic economic theory, it is assumed that information is symmetric in the market and the transaction can be executed without cost. In reality, however, markets are often inefficient. A consequence of Williamson's definition is that it is limited to situations where resources are physically transferred. Those physical transfers may occur within the firms as well as between firms, using markets. Thus, there are internal transactions within the firm and market transactions, which can be understood as a result of labor division (Richter, 1999).

Commons (1934) defines transaction as the transfer of the property right on a good or service, which does not consider only the physical transfer, but also the transfer in terms of property and rights of using a resource, which leads to the contracts related to the use of resources.

In order to proceed with a transaction, producer must search for information and monitor the ongoing process to ensure a favorable deal. The costs involved in such transaction-related activities are called transaction costs. In economics and related disciplines, a transaction cost is a cost incurred in making an economic exchange (restated: the cost of participating in a market). Transaction costs can be divided into three broad categories (Coase, 1937):

1. Search and information costs are costs such as in determining that the required good is available on the market, which has the lowest price, etc.

2. Bargaining costs are the costs required to come to an acceptable agreement with the other party to the transaction, drawing up an appropriate contract and so on. In game theory this is analyzed for instance in the game of chicken. On asset markets and in market microstructure, the transaction cost is some function of the distance between the bid and ask.

3. Policing and enforcement costs are the costs of making sure the other party sticks to the terms of the contract, and taking appropriate action (often through the legal) if this turns out not to be the case.

Transaction Cost Economic is part of the new institutional economics research tradition. The main focus of TCE is the definition of the determinants of coordination of the transactions through markets or hierarchies (Joskow, 1988). In this sense, the boundaries of the firm should be a function of the governance structure (Williamson, 2002 and 2005), especially when we consider that this governance structure would assure the optimal adaptability of the firm to changes in the conditions of supply and demand. One important aspect of TCE is that it focus not only on the two extremes of transaction governance (that is, hierarchy vs. market), but also on other hybrid forms and long term contracts. 
Transaction cost economics (TCE) is most commonly associated with the work of Oliver Williamson $(1975,1979,1981$, and 1985). Rooted in the economic theory, TCE theoretically explains why a transaction subject favors a particular form of transaction over others. The basic principle of TCE is that people like to conduct transactions in the most economical way. Williamson in 1981 assumed that firms pursued profit maximization, and that profit maximization required costs minimization. Implicitly, TCE is an equilibrium theory that assumes rationality on the part of owners and/or managers. Transaction cost theory (TCT) has been successfully applied in many domains. Among the well-known examples are TCT applications to forward vertical integration (John, 1988), contract typology (Adler, 1988), and collaboration of buyer-seller relationship (Sriram, 1992). In the area of agriculture, TCT has been applied to explain many issues at the firm or individual level.

\section{History of Theory Development}

The idea that transactions form the basis of an economic thinking was introduced by the economist John in 1931. He said that: These individual actions are really trans-actions instead of either individual behavior or the "exchange" of commodities. It is this shift from commodities and individuals to transactions and working rules of collective action that marks the transition from the classical and hedonic schools to the institutional schools of economic thinking. The shift is a change in the ultimate unit of economic investigation. The classic and hedonic economists, with their communistic and anarchistic offshoots, founded their theories on the relation of man to nature, but institutionalism is a relation of man to man. The smallest unit of the classic economists was a commodity produced by labor. The smallest unit of the hedonic economists was the same or similar commodity enjoyed by ultimate consumers. One was the objective side, the other the subjective side, of the same relation between the individual and the forces of nature. The outcome, in either case, was the materialistic metaphor of an automatic equilibrium, analogous to the waves of the ocean, but personified as "seeking their level." But the smallest unit of the institutional economists is a unit of activity -- a transaction, with its participants. Transactions intervene between the labor of the classic economists and the pleasures of the hedonic economists, simply because it is society that controls access to the forces of nature, and transactions are, not the "exchange of commodities," but the alienation and acquisition, between individuals, of the rights of property and liberty created by society, which must therefore be negotiated between the parties concerned before labor can produce, or consumers can consume, or commodities be physically exchanged". The term "transaction cost" is frequently thought to have been coined by Ronald Coase, who used it to develop a theoretical framework for predicting when certain economic tasks would be performed by firms, and when they would be performed on the market. Coase (1937) introduced the concept of transaction costs in his famous paper "the nature of the firm". Coase suggested that the use of the market involves extra costs, such as the costs of information search, bargaining and signing contracts. These costs can be eliminated or decreased by organizing these activities under the agent's own supervision (Figure 1).

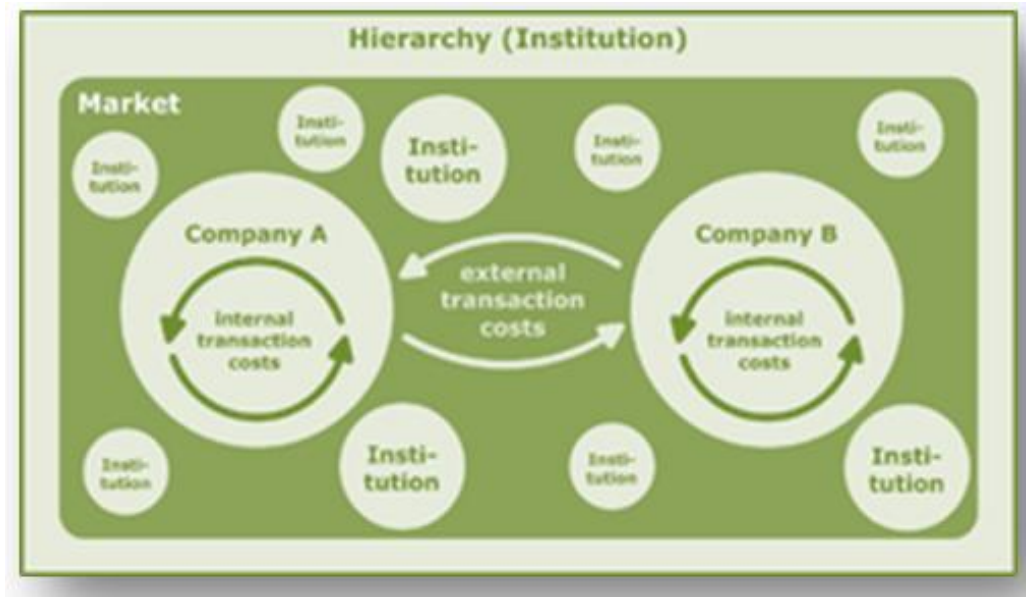

Figure 1: Diagram illustrates the collection between institutions and market in decision making. Source: Coase, R. The nature of the firm, Economica, v. 4, n. 16, Article 1937.

The collection in figure 1 shows institutions and market as a possible form of organization to coordinate economic transactions. When the external transaction costs are higher than the internal transaction costs, the company will grow. If the internal transaction costs are higher than the external transaction costs the company will be downsized by outsourcing. However, the term is actually absent from his early work up to the 
1970s. While he did not coin the specific term, Coase indeed discussed "costs of using the price mechanism" in his paper, and refers to the "Costs of Market Transactions" in his seminal work, The Problem of Social Cost (Coase, 1960). The term "Transaction Costs" itself can instead be traced back to the monetary economics literature of the 1950s, and does not appear to have been consciously 'coined' by any particular individual.

Arguably, transaction cost reasoning became most widely known through Oliver E. Williamson's Transaction

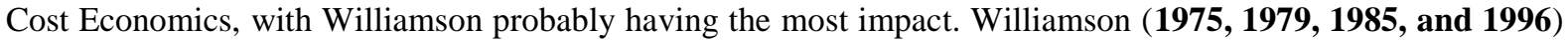
developed the theoretical foundations of the theory with respect to traditional industrial processes and goods, and applied it to different forms of contract. Today, transaction cost economics is used to explain a number of different behaviors. Often this involves considering as "transactions" not only the obvious cases of buying and selling, but also day-to-day emotional interactions, informal gift exchanges, etc. Oliver E. Williamson was awarded the 2009 Nobel Memorial Prize in Economics. According to Williamson, the determinants of transaction costs are frequency, specificity, uncertainty, limited rationality, and opportunistic behavior:

Opportunism with guile: In neoclassical economics, humans are viewed as self-interested; individuals pursue their own self-interest in their own activities [i.e., simple self-interest according to Williamson (1985)]. Opportunism with guile takes this assumption a step further to assume that individuals may engage in behavior that is both subtly and overtly deceitful ex ante and ex post to agreeing on contracts. As Williamson (1985) puts it "Plainly, were it not for opportunism, all behavior could be rule governed". In fact, it is precisely because sometimes some individuals behave opportunistically that there are costs to exchange (e.g., contracts cannot be written and enforced perfectly or costless). The opportunism assumption is about the motivations of human behavior (Williamson, 1985). This assumption is central to TCT because, in the absence of potentially opportunistic behaviors, contracts would be costless enforced and there would be no reason for other forms of economic organization besides the market.

Limited rationality: The neoclassical theory assumes that individuals have perfect information and act as utility maximizes with calculative rationality. In sharp contrast, the TCT views human as bounded rational individuals are "extendedly rational, but only limitedly so" (Simon, 1961). Bounded rationality reflects individuals' inability to process large degrees of information and their difficulty in assigning probability values to the occurrence of future events. It is worth noting that bounded rationality does not imply that individuals seek to be irrational. In fact, they seek to make rational decisions but within the limits of their imperfect cognitive abilities and in conditions of imperfect information.

Asset specificity: Williamson defined asset specificity as "durable investments that are undertaken in support of particular transactions, the opportunity cost of which investment is much lower in best alternative uses or by alternative users should be original transaction be prematurely terminated" (Williamson, 1985). In contrast to the neoclassical economics which treats exchanges of standard nature, transactions according to TCT often involve idiosyncratic attributes so that contracts cannot be written costless due to, for example, the unknown idiosyncrasies beforehand. In this respect Williamson (1985) states that "[transactions that are supported by investments in durable, transaction-specific assets experience 'lock in' effects, on which account autonomous trading will commonly be supplanted by unified ownership". Hence contractual and organizational safeguards (i.e., firms) become necessary for transactions involving these nonstandard assets.

Transaction costs theory focuses rather strongly the asset specificity and its role in determining how to better organize exchanges. The broad advice is that when assets are not specific to an exchange the market may be the most efficient way (or the best way for minimizing costs) to organize it. The asset specificity makes specific reference to the extent to which an asset can be redeployed to alternative uses and/or by alternative users without a substantial sacrifice of its productive value (Williamson, 1989). And, it is possible to distinguish six different types of asset specificity: site specificity, physical asset specificity, human asset specificity, dedicated assets, brand name capital and temporal specificity (Williamson, 1989). The degree of asset specificity ranges from nonspecific to mixed to idiosyncratic (Williamson, 1979 and 1985). The asset specificity assumption might be called the locomotive or driving assumption of TCT as Williamson himself states "the importance of asset specificity to transaction cost economics is difficult to exaggerate" (Riordan, 1985).

Uncertainty: Uncertainty is a straightforward assumption and it contrasts with the perfect-information assumption of the neoclassical view. Information about past, current and future states are not perfectly known, for various reasons. Without the existence of bounded rationality and opportunism, uncertainty would be much less of a problem because general rules would generally prevail (Williamson, 1985). However, given these assumptions uncertainty is especially critical. Uncertainty arises from, for example, not knowing about future states or/and the inability to determine who is more prone to behave opportunistically (Williamson, 1996). Because it is very difficult to determine ex ante who will engage in opportunistic behavior, contracts are not costless written and enforced (Williamson, 1996). 
Frequency of the transactions: If transactions are infrequent then the costs of alternative governance structures may not be justified. A larger frequency or larger volumes of transactions, however, gives rise to justification for alternative governance structures such as the firm. Therefore the volume, number, and/or temporal spread of transactions are important to be considered because even given the previous assumptions if they are infrequent alternative governance structures may not be necessary or feasible. The degree of frequency ranges from occasional to recurrent (Williamson, 1979 and 1985).

Other authors introduced complexity (Shelanski and Klein, 1995), measurability (Barzel, 1982), and Level of investment and Length of contractual relationship (Zeller 1990) as additional attributes. These dimensions help to explain which contractual arrangements are most suitable for a certain type of transactions:

Complexity: The complexity of the contracts between the transaction partners those are appropriate to assure their satisfaction.

Measurability: The possibilities of the farmer receiving the service of the machine to measure the quality of this service.

Level of investment: The amount of capital to be invested in each contract in order to have access of the services.

Length of contractual relationship or amortization period influencing strategic flexibility: For how long are farm activities limited through the decision choosing a certain contractual arrangement to have access to mechanization?

Figure 2 shows the hypothesized relationship among the three factors of transaction cost and outsourcing decision.

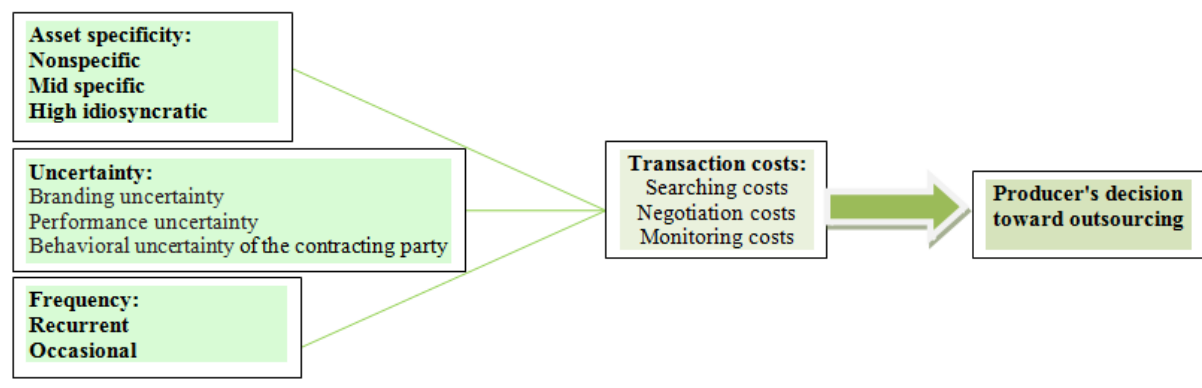

Figure 2: Flowchart illustrates transaction costs attributes as a theoretical framework

Source: Williamson, O. (1975, 1979, 1985, and 1996). Transactions cost economics (TCE), different articles.

In summary, the real illuminating power of TCE comes from the three dimensions or variables that are employed to characterize any transaction. They are frequency, uncertainty and asset specificity. Transactions can be rare or frequent; have low or high uncertainty; or involve specific or non-specific assets.

\section{Governance Structures (Types of Contractual Arrangements)}

In 1985 year, Williamson considers the main contractual agreements for provision of services can be divided into three groups:

1. Market arrangements: A market transaction occurs if a farmer hires a machine from a provider without establishing any relationship with the provider. In a typical agricultural setting, this pure "spot market" for machinery services does not appear to be very relevant, because of information asymmetries. Farmers prefer to continuously hire machinery from the same provider with whom they establish a relationship of trust. Farmer contractors represent the most market-oriented solution among the available contractual arrangements. But even here some social relationships between provider and client can be found, built on trust and interest in long-term customer relationship.

2. Hierarchical arrangements: If a farmer purchases the machine for his farm, one can interpret this as a "hierarchical arrangement" in Williamson's sense (1985) because the transaction is organized within the farm enterprise (hierarchy) rather than hired in form of a market transaction. If a farmer establishes a longterm relational contract with an enterprise to hire in machinery services, this can also be considered as a hierarchical arrangement.

3. Co-operative arrangements: In principle it is useful to consider three different types of co- operative arrangements: (A) informal sharing (= sharing of machinery and work between neighbors without cash payment, which in the region occurs mainly on farms with smaller area), (B) farmer groups (= informal group of farmers, who buy machinery together and use it within the group. Often extended family members and neighbors), and (C) Cooperatives (= formal organized larger group of farms, where farmers are members and pay annual fees and the machinery belongs to the cooperative).

Contracts Matrix and the Conventional Governance Structure Choice 
The match of governance structures with transactions attributes those results from these previous economizing efforts is shown in Figure 3.

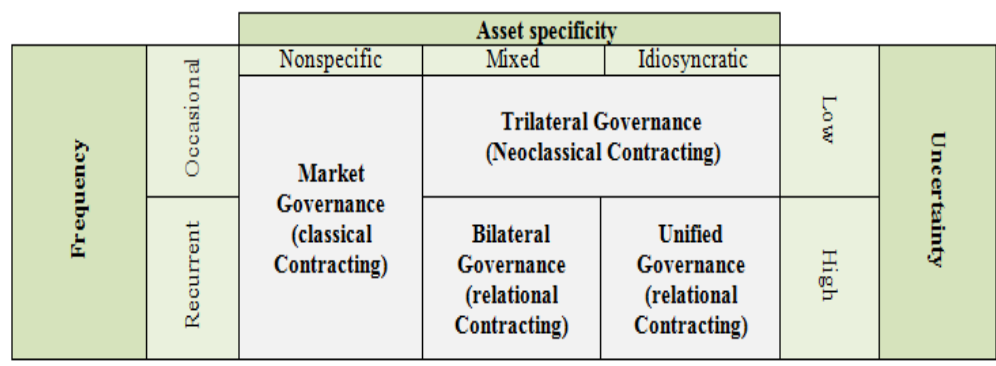

Figure 3: Contracts Matrix of different Governance Structures

Source: Williamson O. (1979). Transaction cost economics: the governance of contractual relations. Journal of Law and Economics, Vol. 22, no. 2, p. 253.

This figure shows that internalization will be preferred to externalization if three conditions are verified: (A) The degree of the transaction uncertainty is high - that is, if it's difficult to guarantee the execution of the contract - the supplier may have an opportunistic behavior that impairs the customers; (B) If the assets involved in the transaction are specific - if just a restricted number of suppliers possess the necessary equipment to the accomplishment of the activity, his bargaining power increases - affects negatively the price of the transaction; (C) If the transaction is the recurrent type, that is, if the firm has to buy regularly large quantities of the product to the suppliers these will be able to demand better conditions.

Finally, transaction cost analysis is useful, although there are some limitations. Williamson (1985) highlights the measurement problems of transaction costs. He concludes that transaction costs can be compared between two different structures, but hardly measured. Unlike the accounting costs of production, it is difficult to measure transaction costs. Apart from that, some writers criticize Williamson's theory for its static limitations. They claim it is not useful in analyzing processes or evolution, since it does not include time. Much of this critique is certainly relevant, as argued by Fahlbeck (1996), but explaining and analyzing the process or structural change was not the main purpose of the transaction cost theory, but instead the emphasis was on awareness of existing positive transaction costs.

\section{Some Empirical Studies Related To Transaction Costs Theory}

Empirical studies on transaction costs exist for some areas, but there are only few trying to estimate transaction costs. Most studies recognize the existence and importance of transaction costs, but only a few try to measure them. Important contributions to measuring transaction costs were done by Crocker \& Masten (1996), Lyons (1994), and Shelanski \& Klein (1995). The limited number of empirical studies on transaction costs is justified by the difficulty in measurement. Picot (1981), goes further, saying that it is very hard to value transaction costs, particularly ex-ante, e.g. cost for seeking, contract formulation and control. However, they are real and significant economic importance. Zylbersztajn (2005), discusses the relevance of the contract approach to the theory of the firm, presents the evolution of the studies of coordination in food chains in Brazil and abroad, and concludes a research and educational agenda for applied agricultural economics.

Regarding its type, the empiric studies available in worldwide literature on transaction costs can be classified into: qualitative case studies, quantitative case studies, and cross sectional and panel regressions. The focus of those studies can be, from micro to macro, at contract level, at governance level and at institutional level (Altman, 2007). Considering the condition and goods or services involved in the transaction, farmers can be supplier and demander of goods and services. We shortly show eight selected studies:

Study 1: ((Transaction cost analysis of outsourcing farm administration by Belgian farmers)). This study documented by Vernimmen, T., Verbeke, W., and Huylenbroeck, G. V. (2000) to provide an empirical evidence of the application of the transaction costs theory in farm management area. In this article, an attempt is made to analyze decisions about farm administration from the farmer's viewpoint. The option of outsourcing administration is analyzed in detail. Outsourcing has been described as particularly important for small businesses because of their limited resources and competence in the specific administrative areas concerned. In this research into the outsourcing decision of farm administration, some of the quantifiable factors that influence decision making are identified such as age of the farmer, the farm size, and the time variable, using farm survey data of 385 farmers. The theoretical framework for the analysis comes from transaction cost economic (TCE), which has previously been adapted to research concerning outsourcing decisions in industrial processes. The empirical analysis uses a discrete choice probit model. On the basis of the model estimates, probabilities of outsourcing farm administration are simulated. The study included five sections: section 1 presents an introduction and the aim of study, section 2 describes the local Belgian situation and summarizes results from the original more descriptive study on farm administration in Belgium, section 3 discusses the theoretical 
framework that is based on TCE, and introduces the probit model specification for the empirical analysis, section 4 covers data collection and categorization, and section 5 presents and discusses the empirical results. In this study, the authors considered groups of administrative tasks which are: the fiscal declaration, management accounting, manure regulations, building and operating permits, CAP administration, and environmental programmes. The properties of each of these types of administrative tasks with respect to transactions cost attributes are shown as in the following table based on survey sample data:

\begin{tabular}{|l|c|c|c|}
\hline & Complexity & Uncertainty & Frequency \\
\hline Fiscal declaration & 3 & 3 & 1 \\
\hline Management accounting & 2 & 1 & $<1$ \\
\hline Manure regulation & 2 & 2 & $>1$ \\
\hline Building and operation permits & 3 & 2 & $<1$ \\
\hline CAP administration & 2 & 2 & 1 \\
\hline Environmental programmes & 1 & 1 & $<1$ \\
\hline
\end{tabular}

To test whether outsourcing depends on the specificity of the transaction, the authors introduced three task- specific variables with the scores from the above table were used as a first set of explanatory variables. The first one is the complexity variable (COMP); the second variable (UNC) refers to the possibility to reduce the uncertainty and risks linked to the outcome of the task; and the third variable is task frequency (FRQ) and measures the scope of outsourcing to reduce the number of times the farmer transacts for this variable, the original scores are reorganized into two relevant categories: $\mathrm{FRQ}=0$ for tasks with a score lower than one and $\mathrm{FRQ}=1$ for tasks with a frequency equal to or higher than one. The analysis of data indicated that there is a significant relationship between a set of independent variables which are included in the study and outsourcing decision.

Study 2: ((Can transaction cost economics explain the different contractual arrangements for the provision of agricultural machinery services? a case study of Brazilian state of Rio Grande Do Sul)). This study documented by Wander, A. E., Birner, R., and Wittmer, H (2003). This document aimed to contribute to filling a gap of the lack of empirical studies to use of new institutional economics concepts (NIE) to analyze the choice of contracts concerning the use of agricultural machinery, while this concept (NIE) has been widely applied to analyze contract choice with regard to labor, land and credit contracts, taking a case from Rio Grande do Sul, the southernmost state of Brazil, as an example. This paper was preceded as follows: Section 2 introduces the empirical case and highlights the contractual arrangements to be explained. Section 3 outlines an analytical framework that includes a number of extensions of the "classical" TCE framework. Section 4 applies this analytical framework to the empirical case. Section 5 discusses the results and Section 6 finally draws some conclusions. Methodology of the study was used descriptive Analysis of transactions costs attributes (asset specificity, uncertainty, frequency, complexity, measurability, group activities, planning time, investment level, and special hold up), and an empirical case study of a random sample of 121 farms. The analysis of data indicated that the possibilities of TCE to analyze the contractual arrangements concerning machinery services and the classical framework of TCE can be extended to account for peculiarities of transactions in this field.

Study 3: ((Transaction cost and their implications to formation of contractual arrangements: aspects of machinery contracting by family farmers in the Centro- Serra region of Rio Grande Do Sul)). This study documented by Wander, A. E., and Zeller, M. (2004). The main objective of the study was to assess the role of transaction costs in the choice among alternative contractual arrangements for provision of machinery services. Methodology of the study was used the empirical data on conventional machinery and transaction costs were collected from farms in southern Brazil that procure services for maize harvest. For analytical purposes, the authors considered co-operative forms next to markets and hierarchies as a distinct type of organization, because these co-operative organizations are by definition non-hierarchical and have to overcome the problems of collective action that are quite different from the principle-agent problem typically found in hierarchical relations. In the agricultural sector, the state often also plays a role as provider of services and has, therefore, to be considered as a further distinct type of organization. Considering markets, hierarchies, co-operatives and state agencies as four basic types of organization, the contractual arrangements found in our Brazilian case study can be classified as followed:

1. Market arrangements.

2. Hierarchical arrangements.

3. Co-operative arrangements.

4. Contractual arrangements with state agencies: If, for instance, local governments own the machines and provide services to farmers against monetary payment. 
The authors found that transaction costs can be higher than conventional machinery costs, and therefore, influence the choice of contractual arrangement. The estimates of TCs done cannot be generalized. Each farm has different conditions and, therefore, has to be analyzed separately.

Study 4: ((Marketing channel selection by cattle farmers in china: A transaction cost approach)). This study documented by Gong, W., Parton, K., Zhou, Z., and Cox, R. J. (2006) to provide an empirical evidence of the application of the transaction costs theory in cattle farmers. This study aimed to illustrate the factors that influence cattle farmers' marketing channel selection and explained the reasons behind a shift from spot market to direct marketing. In order to test the transaction cost based arguments related to the shift in beef marketing channels, a household survey was conducted on cattle producers using a structured questionnaire. The survey was conducted between January and December 2004 with 151 farmers, and a binary logic model was used to analyze the determinants of beef cattle farmer's marketing channel selection. The dependent variable in this study is the odd value of cattle marketed through market and middlemen versus selling directly to meat processors or restaurants. While the independent variables in this study may be divided into four groups: The first group includes price fluctuation, information access, and quality inspection. The second group is related to negotiation costs, consisting of payment delay, bargaining power, transport costs and farm specialization. The third group contains grade uncertainty and farm service, which can reflect monitoring costs. The last group measures producer characteristics. Data on the type of farming firm (size, profit, nature of the business, etc.) and the socioeconomic characteristics of the producer (age, education, experience, household number, etc.).

Descriptive results showed that selling cattle in the spot market was still the main selection by farmers. $36 \%$ of surveyed farmers had sold cattle solely through the spot market, followed by 22 per cent of them who had sold via a dealer and 14 per cent of them choose selling directly to processors. Only one per cent of respondents had sold cattle directly to feedlots. The rest of farmers (27 per cent) indicated using combined channels. The regression results of the Logit model indicated that there are a significant relationship between a set of independent variables and outsourcing decision. The implications of this analysis can be seen as negotiation costs are the most important among all the transaction costs for the Chinese beef cattle industry.

Study 5: ((Transaction costs of collective action to access maize seeds in Central Valleys of Oaxaca, Mexico)). This study documented by Badstue, B., Bellon, R., Berthaud,J., Juárez, X., Rosas, I., Solano, A., and Ramírez, A. (2006). The aim of study was to explore social arrangements associated with seed transactions among small-scale maize farmers in the Central Valleys of Oaxaca, Mexico, where no formal supply system exists. According to the authors, research in the Central Valleys also indicated that farmers who needed to acquire seed from other farmers experienced some difficulty in finding seed that met their requirements. First, a farmer has to learn who grows which maize variety and investigate the characteristics and performance of the maize of interest. Then he or she must make sure that the information offered is trustworthy and the seed is reliable. Finally, the conditions of acquiring the seed must be negotiated. It therefore appears that acquiring seed of diverse maize varieties under these conditions can entail risks and high transaction costs to individual farmers. Farmers mostly saved seed and only occasionally acquired seed from outside sources. The authors found no evidence of a specialized social organization based on collective action to mediate seed flows. Seed transactions were infrequent, bilateral, and ad hoc, although trust was an important component, as it ensured reliable information about the seed was provided. In the study, the authors identified several different types of seed transactions:

1. Purchase: Seed that has been bought and paid for in cash. It represented more than $52 \%$ of all transactions in the study.

2. Inheritance: When parents or foster parents pass on maize seed to their children or foster children. This can be when the parents die, or when the children become independent of their parents and start to farm on their own.

3. Exchange Seed of one kind of maize is exchanged for the same quantity of seed of another kind of maize. Sometimes seed is acquired in exchange for grain, but then quantities normally vary, as seed has higher value than grain.

4. Gift: In this transaction seed is provided without payment, whether monetary or in kind.

5. Barter: This is an exchange in kind, i.e., maize seed is given for some other good of use to the seed provider (e.g., beans or coffee).

6. Borrowed: The seed provider hands over the seed to the person requesting it, while the latter in turn promises to give back the same quantity of seed of the same kind of maize once it has been harvested.

7. Other: This category contains various other ways of obtaining seed: sharecropping, pepena (gleaning), seed won in a lottery, payment realized in kind with maize, and seed acquired without the knowledge of the seed provider. 
The main seed providers identified by the authors were family members. However, also other providers, like compares, neighbors, friends, Acquaintances, Strangers and others were mentioned as seed providers. The authors identified the lack of records as one of the main difficulties in assessing the frequency of seed transactions. Social relations are of high importance in the selection of seed provider.

Study 6: ((Assessment of transaction costs of dairy farms at formal and informal markets in São Carlos region, São Paulo state)). This study documented by Bánkuti, F. I.; Souza, H. M. D.; and Bánkuti, S. S. M. (2008). The aim of study was to present an analysis and a measurement of the transaction costs for two groups of dairy farms in the region of São Carlos, São Paulo state. The authors measured the transaction costs of dairy farms in accessing formal and informal markets to commercialize their production. Some farmers accessed mainly informal markets, others focused more on formal markets. Both formal and informal markets had low negotiation costs (transaction costs). Operational production costs represented $97 \%$ of total production costs for formal markets. For those farmers accessing informal markets, the operational production costs represented $88 \%$, followed by transport related costs of $11 \%$. The main reasons why transaction costs are low in this study are related to the fact that since milk is a perishable product, farmers will avoid any kind of conflict. Contract breaches were not common, also because of passive behavior of farmers. From the sample of dairy farms considered, the authors concluded that transaction costs are low for all considered farms. However, those farms that access mainly informal markets had relatively higher transaction costs than farmers accessing formal markets. The authors also observed that only a few contracts are available, which is related to the high frequency of transaction for marketing dairy production and the resulting establishment of reliability among transaction partners.

Study 7: ((Transaction costs in agriculture: from the planting to selling at the wholesale market)). This study documented by Silva, H. D., Ratnadiwakara, D., and Soysa, S. (2010). The objective of the study was to identify the information based transaction costs faced by farmers in the initial stages of a value chain to determine the potential of Information Communication Technologies (ICTs) in the reduction of such cost. The study included five sections: section 1 presents an introduction and the aim of study, Section 2 introduces various definitions and classifications of transaction costs and studies that look at how ICTs can reduce transaction costs. The research methodology is presented in section 3 and results are presented in section 4 . Finally the section 5 discusses the possible policy implications. The study was conducted in the immediate feeder area to the Dambulla Dedicated Economic Centre (DDEC) among selected smallholder farmers. Given the large variety of vegetables sold at DDEC, the four mostly traded vegetables by volume; tomato, onion, eggplant and chili were considered in the study. A questionnaire-based survey was conducted among a sample of these farmers. The DDEC, located at almost the island's geographic center was formally established in 1999 to accommodate the sustained organic growth of an informal market that was created in that location many years ago, the number of farmers was 89 farmers who were selected using a simple random sampling technique.

For the purpose of this study, search cost is defined broadly as the costs including an associated with information-based transaction costs that can be reduced by using alternative sources such as ICTs for obtaining the same information. For example, farmers can reduce all the costs incurred in unsuccessful visits to purchase fertilizer if they use phones to obtain information on its availability on the day of the visit. Such costs are classified as 'search cost'. The results indicated that the information related costs from $70 \%$ of the total transaction costs, which is $15 \%$ of the total production cost, incurred by these farmers; it is argued that simple mobile phones can reduce these costs significantly. Such information can help farmers not only in deciding where and at what price to sell their produce, but also in reducing the high search costs associated with locating outlets that has (subsidized) fertilizer available for distribution on a given day.

Study 8: ((Reduction of transaction cost within the South African potato processing industry $))$. This study documented by Strydom, D. B., Terblanche, L., Zyl, H., and Willemse, B. (2012). The aim of this study was to assist potato processing companies in South Africa to establish long-term relationships with producers and also to reduce producers' transaction costs. Questionnaires were used to determine the magnitude of transaction costs within the potato industry. Interviews were held with the managers of five successful alliances within the potato industry in order to establish if the alliance assisted in overcoming market obstacles and what elements should be in place in order to build a successful long-term relationship with their buyer. Methodology of the study was used the descriptive Analysis of transactions costs attributes, and the study area consists of the eastern free State region which is the region that represents the table and processing industry the best in terms of concentration. The population of table potato and processing potato producers in the eastern Free State were 70 producers. The results indicated that the contract market has the lowest transaction costs as well as by forming an alliance, producers were able to overcome the obstacles they faced and the elements which should be in place were sound administration, trust and loyalty, market research, marketing and traceability. The results also indicated that 
there are transaction costs within the potato industry and these transaction costs can be managed with the use of alliances.

\section{Conclusions}

Agricultural contracts can have many beneficial effects. They can help farmers manage price and production risks, they can elicit the production of products with specific quality attributes by tying prices to those attributes, and they can smooth flows of commodities to processing plants, thus encouraging more efficient use of farm and processing capacities. But contracts can also have less benign effects. They can introduce new and unexpected risks for farmers - in some circumstances, they can extend a buyer's market power - and they can effect fundamental changes in how farming is organized and carried out.

In this our article we address transaction cost theory (TCT) in some details as a theoretical framework in study of methodology of agreements and contracts, for proving the role and importance of this theory on agriculture contracting area based on eight empirical studies on assessing transaction costs in different farms. Main finding is there are diverse opinions on the applicability of the transaction costs theory in agricultural contracting scope of different management decision-making processes. These opinions developed over a long period of time following continuous improvement on the application of the theory in solving of the outsourcing business problems. Most literature in economic development supports the view that transaction costs theory is a practical tool to analysis the different contractual arrangements for the provision of agricultural processes services. These studies also proved that TCs are difficult to measure and there is no standard procedure to assess transaction cost, but they can and should be estimated because they are important cost elements in the decisionmaking process concerning the choice of contract for different outsourcing agricultural production stages.

\section{References}

[1]. Adler T. Scherer R. Barton S. and Katerberg R. 1988. An empirical test of transaction cost theory's validating contract typology. Journal of Applied Management Studies; 7(2):pp. 185-200.

[2]. Altman I. J. Klein P. G. and Johnson T. G. 2007. Scale and transaction costs in the U.S. Biopower industry. Journal of Agricultural \& Food Industrial Organization, v. 5 (Article 10).

[3]. Badstue B. Bellon R. Berthaud J. Juárez X. Rosas I. Solano A. and Ramírez A. 2006. Examining the Role of Collective Action in an Informal Seed System: A Case Study from the Central Valleys of Oaxaca, Mexico. Human Ecology. Vol. 34, No. 2, pp. 249-273.

[4]. Bánkuti F. I. Souza H. M. D. and Bánkuti S. S. M. 2008. Measurement and transaction cost analysis borne by milk producers in the formal and informal markets of São Carlos region, SP. Rural Organizations \& Agribusiness, v. 10, no. 3, pp. 343-358.

[5]. Barzel Y. 1982. Measurement cost and the organization of markets. Journal of Law and Economics, v. 25, pp. $27-78$.

[6]. Coase R. 1937. The nature of the firm. Economica, v. 4, n. 16. pp. 386- 405.

[7]. Coase R. 1960. The problem of social cost. Journal of Law and Economics, v. 3, pp. 1- 44.

[8]. Commons W. 1934. Institutional economics: it's place in political economy. New York: Macmillan. p. 58.

[9]. Crocker K. and Masten S. 1996. Regulation and administered contracts revisited: lessons from transaction-cost economics for public utility regulation. Journal of Regulatory Economics, v. 9, n. 1, pp. 5- 39.

[10]. Fahlbeck E. 1996. Essays in transaction cost economics. Swedish University of Agricultural Sciences, Sweden.

[11]. Gong W. Parton K. Zhou Z. and Cox R. J. 2006. Marketing channel selection by cattle farmers in china: A transaction cost approach. International conference on "emerging china: internal challenges and global implications", Victoria university, Melbuome, Australia, pp.1-13.

[12]. Hagedorn K. 2008. Particular requirements of institutional analysis in nature-related sectors. European Review of Agricultural Economics, v. 35, n. 3, pp. 357-384.

[13]. Ivanaj V. and Franzil Y. M. 2006. Outsourcing logistics activities: a transaction cost economics perspective. XV Conference international of management strategy, Annecy/ Genève 13- 16 June, pp. 1- 25.

[14]. John G. and Weitz B. 1988. Forward integration into distribution: an empirical test of transaction cost analysis. Journals of Law, Economics, and Organization; 4(2):pp. 101-17.

[15]. Joskow Paul L. 1988. Asset Specificity and the Structure of Vertical Relationships: Empirical Evidence. Journal of Law, Economics and Organization, 4, pp. 95- 117.

[16]. Key Nigel. 2004. Agricultural Contracting and the Scale of Production. Agricultural and Resource Economics Review 33: pp. 255271.

[17]. Lyons B. R. 1994. Contracts and specific investment: an empirical test of transaction cost theory. Journal of Economics \& Management Strategy, v. 3, n. 2, pp. 257-278.

[18]. Macdonald J. Janet P. Mary A. David B. William C. Carolyn D. Nigel K. Kenneth N. and Leland S. 2004. Contracts, Markets, and Prices: Organizing the Production and Use of Agricultural Commodities. Agricultural Economics Report No. 837. USDA, Economic Research Service.

[19]. Macdonald J. M. and Penni K. 2011. Agricultural Contracting Update: Contracts in 2008. EIB-72. U.S. Dept. of Agriculture, Econ. Res. Service.

[20]. Parmigiani A. 2007. Why do firms both make and buy? An investigation of concurrent sourcing. Strategic management journal. 28, pp. 285- 311.

[21]. Picot A. 1981. Transaction cost theory of organization. Hannover: Chair of Business Studies, University of Hannover.

[22]. Richter R. and Furubotn E. G. 1999. New institutional economics: an introduction and critical appreciation. Second edition, Tubingen: Rout ledge.

[23]. Riordan M. H. and Williamson O. E. 1985. Asset Specificity and Economic Organization. International Journal of Industrial Organization, North-Holland, VOL, 3, PP. 365-78.

[24]. Shelanski H. A. Klein P. G. 1995. Empirical research in transaction cost economics: a review and assessment. Journal of Law, Economics and Organization, v. 11, n. 2, pp. 335- 361. 
[25]. Silva H. D. Ratnadiwakara D. and Soysa S. 2010. Transaction costs in agriculture: from the planting to selling at the wholesale market. The international development research centre, Ottawa, Canada, pp. 1- 18.

[26]. Simon H. 1961. Administrative Behavior. 2nd Ed, New York, Macmillan.

[27]. Sriram V. Krapfel R. and Spekman R. 1992. Antecedents to buyer-seller collaboration: an analysis from the buyer's perspective. Journal of Business Research; 25:pp. 303-21.

[28]. Strydom D. B. Terblanche L. Zyl H. and Willemse B. 2012. Reduction of transaction cost within the South African potato processing industry. African Journal of Agricultural Research, Vol. 7(47), pp. 6265-6273.

[29]. Turkey M. S. 2008. Business economics. First edition, university book shop, Ithraa of publishing and distribution, Oman - Jordan. pp. 25-35.

[30]. U.S. Department of Agriculture, Office of Communications. 2010. USDA Announces Proposed Rule to Increase Fairness in the Marketing of Livestock and Poultry. Release No. 0326.10.

[31]. Vernimmen T. Verbeke W. and Huylenbroeck G. V. 2000. Transaction cost analysis of outsourcing farm administration by Belgian farmers. European review of agricultural economics, vol. 27, n. 3. pp. 325- 345.

[32]. Wander A. E. Birner R. and Wittmer H. 2003. Can transaction cost economics explain the different contractual arrangements for the provision of agricultural machinery services? A case study of Brazilian state of Rio Grande Do Sul, Brazilian Journal of Theoretical and Applied Economics, v. 11, n. 20, pp. 9 - 26.

[33]. Wander A. E. and Zeller M. 2004. Transaction cost and their implications to formation of contractual arrangements: aspects of machinery contracting by family farmers in Southern Brazil. Quarterly Journal of International Agriculture, v. 41, n. 4, pp. 317-334.

[34]. Williamson O. 1975. Markets and hierarchies: analysis and antitrust implications. New York: Free Press, 286 pages.

[35]. Williamson O. 1979. Transaction cost economics: the governance of contractual relations. Journal of Law and Economics, Vol. 22, no. 2, pp. 233-261.

[36]. Williamson O. 1981. The economics of organization: the transaction cost approach. American Journal of Sociology, Vol. 87, iss.3, pp. 548-577.

[37]. Williamson O. 1985. The economic institutions of capitalism: Firms, markets and relational contracting. New York: The Free Press, 450 pages.

[38]. Williamson O. 1989. Transaction Cost Economics, in Richard S. and Robert W., Handbook of Industrial Organization. Amsterdam: North Holland, Vol. 1, chapter 3, pp. 135-182.

[39]. Williamson O. 1996. Revisiting Legal Realism: The Law, Economics, and Organization Perspective. Oxford Journals, Social Sciences, Industrial and Corporate Change, Vol. 5, iss.2, Pp. 383-420.

[40]. Williamson O. 2002. The Lens of Contract: Private Ordering. Journal of American Economic Review, Vol. 92, No. 2, pp. $438-443$.

[41]. Williamson O. 2005. The economics of governance. Journal of American Economic Review, Vol. 95, No. 2, pp. 1-18.

[42]. Zylbersztajn D. 2005. Role of contracts in agro industrial coordination: a look beyond the markets. Journal of Economics and Rural Sociology, Vol. 43, no. 3, pp. 385-420. 